\title{
Official Website as a Means of Stakeholder Dialogue on Corporate Social Responsibility
}

\author{
Dr. Ati Harmoni (Gunadarma University, Indonesia)
}

\begin{abstract}
As part of the fulfillment of CSR, companies are expected to engage with its stakeholders through an activity called stakeholder dialogue. Stakeholders can demonstrate an interest and influence to the company through direct pressure or through the dissemination of information, acting formally or informally, individually or collectively. The dynamics of the relationship between companies and stakeholders, particularly through the Internet are becoming increasingly attractive because, on one side, the growing demand for transparency in the company - including transparency in CSR programs and activities - and advances in communications technology and information on the other side. This paper will review whether the company's official website allows the dialogue between companies and stakeholders, in particular about CSR. Considering the number of stakeholders who have different interest to the company then the company should provide information and appropriate means of communication for each stakeholder group. A survey conducted on the company website to analyse the facilities provided by the company on its website which is intended to CSR communication and dialogue with stakeholders. The companies selected for this study were public company listed on Indonesia Stock Exchange and included in Bisnis-27 index and must have an accessable official website. The study was conducted by observing information about CSR presented on the web and the used of web interactivity features. The results indicate that the company has tried to show information about the CSR on the website but not yet fully take advantage of the interactivity features to establish a dialogue with stakeholders.
\end{abstract}

JEL codes: D83, M14

\section{Introduction}

Corporate Social Responsibility (CSR), a concept whereby companies integrate social and environmental concerns into their business operations and interactions with their stakeholders on a voluntary basis, has become a much-discussed subject in the business world. CSR is characterized by three areas of responsibility. The economic focus maintains growth and profitability. The legal focus provides legitimacy and compliance. Ethical practices guide right behaviour and the full commitment to CSR that goes beyond compliance (Carroll, 1979). The challenge of CSR is to insure a firm's responsiveness to stakeholders and gain competitive advantage. From a business perspective, CSR is considered as an activity that legitimizes an organization in the eyes of society. It was an obligation for corporations to accomplish their responsibilities towards their internal and external environments if they want to be perceived favourably by their stakeholders. These obligations are often embedded in organisational policy and action with the aim to achieve economic, social and environmental sustainabilities (Jenkins and Yakovleva, 2006).

As part of the fulfillment of CSR, companies are expected to engage with its stakeholders through an activity called stakeholder dialogue. Stakeholders can demonstrate an interest and influence to the company through direct pressure or through the dissemination of information, acting formally or informally, individually or collectively. According to Morsing and Schultz (2006), messages regarding corporate ethics and social initiatives have the power to evoke strong positive reactions among stakeholders. As a result, corporations are increasingly concerned with communicating to the diversity of stakeholder groups in an ethical and responsible fashion. This communication with stakeholders is accomplished through a number of communication channels, such as sustainability reports, advertising campaigns on television, billboards, and the Internet. The dynamics of the relationship between companies and stakeholders, particularly through the Internet are becoming increasingly attractive because, on one side, the growing demand for transparency in the company - including transparency in CSR programs and activities - and on the other side, advances in communications technology and information.

The Internet is increasingly becoming one of the main tools for CSR information disclosure. This medium, unlike traditional media (newspapers, magazines, billboards, television and radio), allows the company to publicise detailed and up-to-date information. Moreover, the information remains permanently available on the web, allowing the Internet user to choose which subjects he/she wants to access and as often as he/she wishes. Corporate websites provide an official perspective regarding CSR within the corporation for all its stakeholders. Considering the number of stakeholders who have different interest to the company then the company should provide information and appropriate means of communication for each stakeholder group.

This paper investigates the ways in which the corporations included in Bisnis-27 Index disclose information on CSR through their official websites. A further aim is to address a question whether official website allows the dialogue between companies and stakeholders, in particular about CSR. The rest of the paper is organized in the following manner. Section 2 of this article briefly discuss the stakeholder dialogue and 
web based CSR communication. Section 3 presents research approach, section 4 features the presence of CSR issues on the official websites of the company selected for this study. Section 5 features the dialogic features of the website. The last section will address the discusion and conclusion.

\section{Stakeholders Dialogue and CSR Communication}

The concept of the stakeholder was defined by Freeman (1984) as any group or individual who can affect or is affected by the achievement of the firm's objectives. This general definition was given greater precision by Mitchell, Agle, and Wood (1997) who adopted several identification criteria, the two most basic of which are the power exerted over the company by these groups, and their legitimacy. The first criteria, therefore, is power. It is a necessary condition to the extent that the strategy adopted towards the stakeholders is linked to the resources they control and to their degree of interdependence with the company. The second criteria is the legitimacy of these stakeholders, which is their moral right, over and above the legal context, to intervene in the life of the company. However, this type of legitimacy alone is not enough and must be associated with power in order to lead to an authoritative relationship.

Gray et al. (1987) viewed stakeholders have the right to specific information for certain decision and they should be provided relevant information including environmental information. Stakeholders have the ability to control or affect the resources of corporations. This elucidates their power through their level of control they have over the resources. However, the stakeholder-corporation power relationship is not generic across corporations and that power may take the form of command over limited resources such as finances and labour, access to influential media, ability to legislate against corporations or ability to influence corporations' consumption of goods and services. Thus, the more critical the stakeholders' control is, the more likely companies will satisfy stakeholders' demand. Stakeholder theory is generally concerned with how an organization manages its stakeholders. Organizations are likely to use different strategies to deal with different stakeholders and these strategies may change overtime (Jawahar and McLauglin, 2001). On the other hand, certain stakeholder group can be more effective than others in demanding social responsibility disclosure, thus makes corporation concentrates on the group's information needs and demands.

One way to make CSR more concrete is to formulate it in terms of stakeholder relations. The stakeholder concept can be used to personalize social responsibilities by specifying the specific groups or persons to be concidered. Although stakeholder responsibilities can be defined in very broad and abstract terms as including all individuals or groups that may potentially affected by the actions of the corporation (Freeman, 1984), the strength of the stakeholders approach is that it can be made operational. CSR then becomes of matter of identifying, organizing, communicating with and/or entering into dialogue with pertinent stakeholders. The challange thus lies in being responsive to and balancing a multiplicity of particular interest. Business has come under increasing pressure from its stakeholders to act responsibly and to engage effectively with stakeholders via various dialogue practices. Stakeholder dialogue has come to be seen as part of the broader spectrum of socially responsible action.

While stakeholders previously primarily attributed negative attention to particular industries (i.e. 'sin stocks', including companies producing tobacco, alcohol, weapons, pornography, etc.), today CSR issues have become more unpredictable and changing, and including, for example, child labour, gene-modified organisms (GMOs), hormones, union assembly rights, sweatshops, etc., which in practice are concerns across all industries. Furthermore, the number of CSR rankings and CSR surveillance institutions is increasing. Critical stakeholder attention is not restricted to a company's decisions and actions, but also focuses on the decisions and actions of suppliers, consumers and politicians, which may spur criticism towards a company. In that sense, corporate CSR engagement today requires more sophisticated and ongoing stakeholder awareness and calls for more sophisticated CSR communication strategies than previously.

The corporate annual report has traditionally been seen as the primary vehicle by wich companies have communicated with external stakeholders. However, the annual report is targeted at shareholders and is not necessarily the best option for reporting to other stakeholders. This lead to the questioning of the focus on the annual report as the most appropriate medium for sustainability reporting (Unerman, 2000). More recently, with the advent of the internet, companies have begun to utilize web based technologies as a means of reporting to external stakeholders. The web site provides new ways of communicating with stakeholders, such as the ability for two-way communication, to allow users to quickly navigate the site then to select their information preferences. In other words, corporate communication can evolve from providing simply an electronic version of hard copy reports to an interactive environment where information is formatted to suit the electronic medium (Adams and Frost, 2006). The advent of the world wide web (WWW) has provided management with an alternative means of information dissemination that allow reporting to be tailored by the stakeholder to meet various technical and information needs, but prior research has identified that the development of web based reporting, particularly with the respect to social and environmental issues, has been limited due to both poor use 
of the technology and the failure to integrate social and environmental performance data within the broader reporting framework.

In considering the use of the corporate web site as a communication medium, the obvious potential advantages over hard copy communication can be easily identified, that is the user can determine format of presentation, customize the information they receive through search facilities, and that the web, as an immediate communication medium, can provide real-time data and instant corporate information (Adams and Frost, 2006). The main difference between the Internet and the traditional media lies in the fact that it allows companies to publicise more information less expensively and faster than ever before. It is available $24 \mathrm{~h}, 7$ days a week, and Internet users can select the information they want to see. It provides new features to corporate communication, such as electronic document retrieval, search tools and multimedia applications. The internet also possesses a particular feature that allows the corporation to communicate with specific stakeholders and obtain feedback (Branco and Rodrigues, 2006). A single website can have multiple pages, each directed at a different stakeholder group (Esrock and Leichty, 2000). However, Snider et al. (2003) point out that the Internet also permits stakeholders to gain access to messages intended for other groups that are not their own.

In spite of its great possibilities, the literature review by Isenmann and Lenz (2001) identified the limitations of web based reporting: 1) companies mainly publish single, free standing environmental reports, usually with no link to general corporate communications or other management indicators, 2) significant data on environmental performance is being collated, but these databases are not being linked into corporate environmental reports, 3) companies are not exploiting the benefits of the internet - particularly integrated, efficient, dialogue oriented, hypermedia features, interactive and customized environmental reporting. As a consequence, many corporate web sites are difficut to navigate for less experienced users.

\section{Research Approach}

An investigation was done to the official websites of the 27 companies studied. Two categories were established: content categories and dialogue feature categories. The content category served to identify the issues included in CSR based on the work of Capriotti and Moreno (2007). Ten values corresponding to issues related to CSR (Table 1) were identified.

\begin{tabular}{|c|c|}
\hline Issue & Definition \\
\hline Coporate Profile & $\begin{array}{l}\text { Explanation of the enterprise's views, values, and corporate strategy. Presentation of } \\
\text { the company's property, structure, and legal form; divisions, subsidiaries and } \\
\text { countries with which the enterprise operates. Explanation of results }\end{array}$ \\
\hline Products and Services & $\begin{array}{l}\text { Explanation of the enterprise's products, services, and brands from a corporate } \\
\text { perspective and not from a commercial one (type of products, raw materials, } \\
\text { manufacture systems, etc.) }\end{array}$ \\
\hline $\begin{array}{l}\text { Employment and human } \\
\text { resources }\end{array}$ & $\begin{array}{l}\text { Declarations and explanations of its systems of contract, promotion, evaluation, and } \\
\text { dismissal. }\end{array}$ \\
\hline & $\begin{array}{l}\text { Declarations and explanations about human rights in the enterprise (children labour, } \\
\text { discrimination) }\end{array}$ \\
\hline Economic action & $\begin{array}{l}\text { Declarations and actions related to the economic impact of the enterprise in its local, } \\
\text { regional, } \\
\text { national, and supranational environment }\end{array}$ \\
\hline Social action & Declarations and actions related to the enterprise's involvement in social issues \\
\hline Environmental action & $\begin{array}{l}\text { Declarations and actions related to the enterprise's involvement in environmental } \\
\text { issues }\end{array}$ \\
\hline Corporate governance & $\begin{array}{l}\text { Declarations and explanations of the enterprise's transparency, compromises in the } \\
\text { governance of the company. Explanation of the structure of power, remunerations, } \\
\text { responsibilities, government departments, etc. }\end{array}$ \\
\hline Corporate ethics & $\begin{array}{l}\text { Declarations and explanations about the enterprise's ethical compromises in relation } \\
\text { with the business and its groups of public }\end{array}$ \\
\hline $\begin{array}{l}\text { Relationship with } \\
\text { publics }\end{array}$ & $\begin{array}{l}\text { Declarations and explanations about the interests, importance, and linking of the } \\
\text { groups of public with the enterprise }\end{array}$ \\
\hline External criteria & $\begin{array}{l}\text { Declarations, explanations, and linking with the national and international criteria on } \\
\text { aspects of } \\
\text { CSR/CC/SD }\end{array}$ \\
\hline
\end{tabular}

Table 1. Issues of CSR. Source: Capriotti and Moreno (2007)

The dialogue feature catagories served to identify the features or facilities provided by the company on its website which is intended to CSR communication and dialogue with stakeholders. The dialogue resources 
category facilitates the identification of the systems available on corporate websites for visitors to ask questions, give opinions, or assess the CSR issues. Five types of possible forms of dialogic features were laid out: 1) ease of interface; 2) dialogic loop; 3) return visit encouragement; 4) usefulness to media; and 5) conservation of visitors.

The study sample included the corporate official websites of all of the enterprises quoted in November $2011-$ April 2012 in the selective index of the Indonesia Stock Exchange, the Bisnis-27 Index. The Bisnis-27 Index consists of 27 stocks chosen based on fundamental criteria and technical criteria or transaction liquidity. The companies studied included Adaro Energy, Aneka Tambang, Astra International, BNI, BRI, BTN, Bank Mandiri, Bank Danamon, Borneo Lumbung Energi \& Metal, BSD, Charoen Phokphand Indonesia, XL Axiata, Harum Energy, Indofood CBP Sukses Makmur, International Nickel Indonesia, Indofood Sukses Makmur, Indika Energy, Indocement Tunggal Prakarsa, Jasa Marga, Kalbe Farma, Krakatau Steel, PP London Sumatra, PGN, PTBA, Semen Gresik, Telekomunikasi Indonesia, United Tractor.

\section{The Presence of CSR Issues on Official Website}

The Survey showed all of the corporates in the Bisnis-27 present information about CSR on their websites (Figure 1). The most present and relevant issues are those linked to the presentation of the general characteristics of the company (corporate profile) and of its products and services. This reinforces the idea of the selfpresentation function of corporate websites. These issues have an eminently descriptive and informative approach and are more commercial in perspective, rather than allowing an ethical valuation or an appraisal of the company's compromises in its production and marketing activities. Another issue with a high presence is social action. However, more than $72 \%$ of the websites reserve a space for the issues of environmental action, external criteria, and relationship with publics resources. Finally, a remarkable fact is that the issue of corporate governance does not get special attention on the corporate websites, which is only $56 \%$ of website describe about corporate governance.

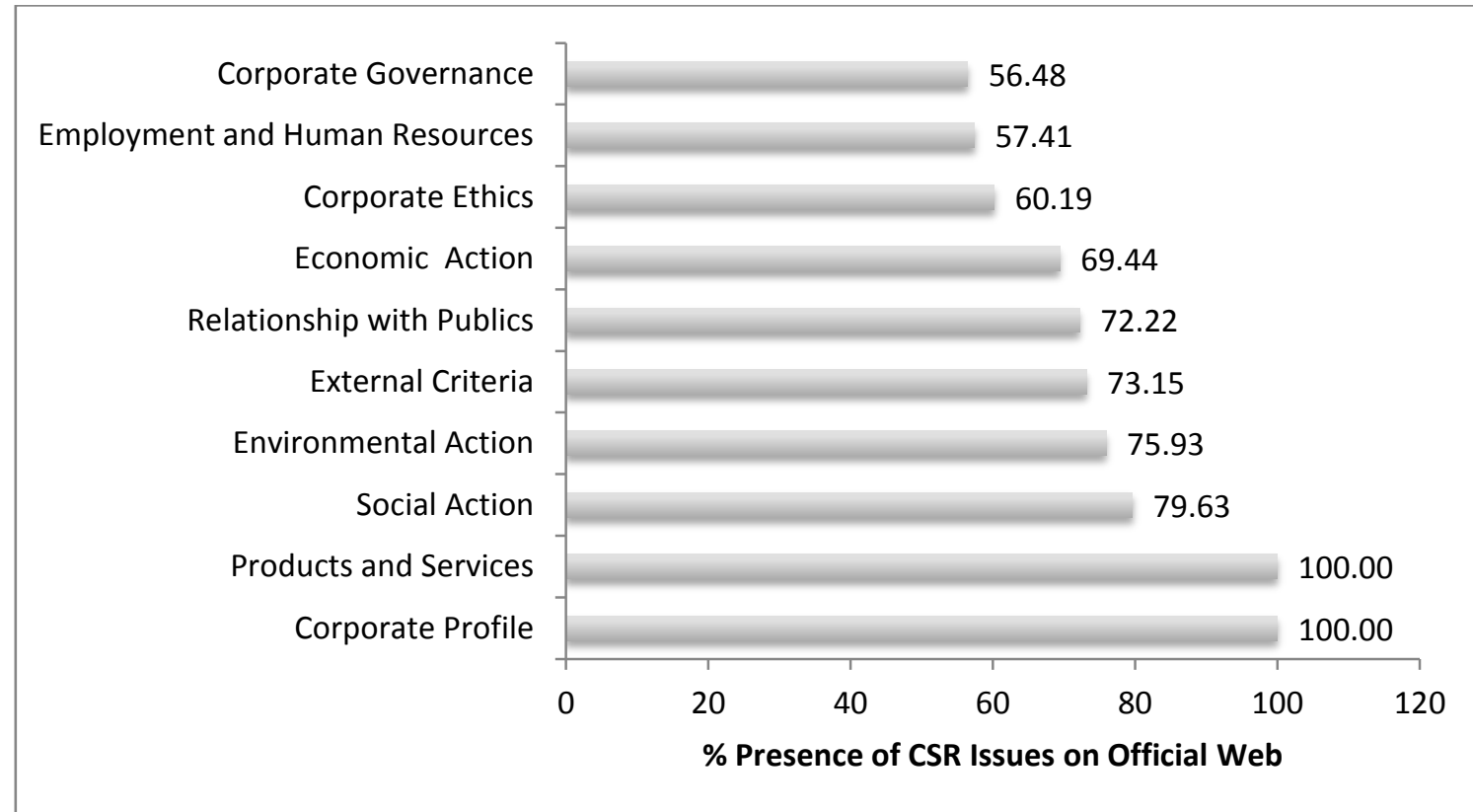

Figure 1. Presence of CSR issues on corporate official website

\begin{tabular}{lr}
\hline Specific Section Related to CSR & \\
\hline Corporate Social Responsibility/CSR & 18 \\
Corporate Community Responsibility & 1 \\
Environment Social Responsibility & 1 \\
Community and Environment & 1 \\
Community Relation & 1 \\
Sustainability & 1 \\
Sustainable Development & 1 \\
Corporate Responsibility & 1 \\
No Specific Section & 2 \\
\hline Total & 27 \\
\hline
\end{tabular}

Table 2. Name of Specific Section Related to CSR on Official Website 
Specific CSR sections also presence on the websites of the Bisnis-27 corporations. Of these, $92.6 \%$ have a specific section, and $7.4 \%$ do not. On websites that have a specific section, CSR emerged as the main menu $(66.7 \%)$, as a sub menu (18.5\%), and the sub sub-menu (7.4\%). The majority call it "Corporate Social Responsibility" (68\%), and the rest were given different names such as "Corporate Responsibility", "Sustainability", "Environment Social Responsibility", "Sustainable Development", "Community and Environment", "Community Relations ", and "Corporate Community Responsibility " (Table 2).

\section{The Dialogic Features of the Website}

Corporate CSR initiatives are important to the general public (Morsing and Schultz, 2006). However, the general public has different perceptions of whether companies should communicate their CSR initiatives in corporate advertising and corporate releases or in minimal releases, such as annual reports and websites. According to Morsing and Schultz (2006), there were three types of stakeholder relations in terms of how companies strategically engage in CSR communication vis-a' -vis their stakeholders: the stakeholder information strategy; the stakeholder response strategy; and the stakeholder involvement strategy.

The stakeholder information model assumes that stakeholders are influential as they can either give support in terms of purchasing habits, showing loyalty and praising the company, or they can show opposition in terms of demonstrating, striking or boycotting the company (Smith 2003). Therefore, the company must inform stakeholders about its good intentions, decisions and actions to ensure positive stakeholder support. The stakeholder response strategy is based on a 'two-way asymmetric' communication model. The model assumes an imbalance from the effects of public relations in favour of the company, as the company does not change as a result of the public relations. The stakeholder involvement strategy assumes a dialogue with its stakeholders. Persuasion may occur, but it comes from stakeholders as well as from the organization itself, each trying to persuade the other to change. the stakeholder involvement strategy suggests that companies engage frequently and systematically in dialogue with their stakeholders in order to explore mutually beneficial action - assuming that both parties involved in the dialogue are willing to change.

The study showed that corporates used limited dialogic features of website to communicate with stakeholders. Of all the features of the dialogic, just ease of interface is used extensively. Other dialogic features are only used on a limited basis (Table 3). The values for each item represents the number of "yes" responses to a dichotomously coded (i.e., yes or no) index item.

\begin{tabular}{lll}
\hline Scale or Item Value & Score & Total Index \\
\hline Ease of Interface & 82.4 & 43.1 \\
Dialogic Loop & 42.6 & \\
Return visit encouragement & 33.8 & \\
Usefulness to Media & 33.3 & \\
Conservation of Visitors & 23.3 & \\
\hline
\end{tabular}

Table 3. Occurance of dialogic features

As with Taylor, Kent, and White's method, "scores for the dialogic principle indices were computed by dividing the number of observed "yes" responses on the items comprising the index by the number of total items in the index and treating the result as a percentage." (Taylor et al, 2002). According to Morsing and Schultz (2006), this indicates that the company is still more use of stakeholder information strategy. That companies concentrates on developing efficient one-way communication as the most preferred way of engaging with stakeholders. Nevertheless, the survey from Morsing and Schultz (2006) warned corporate managers to avoid communicating CSR efforts too conspicuously, as a large percentage of the survey sample subscribe to minimal releases as the most appropriate way of communicating CSR efforts. Too much explanation regarding CSR efforts may be counter-productive. It is argued that companies already perceived as legitimate constituents do not need to communicate their CSR efforts loudly. The promotion of desirable qualities such as CSR will tend to evoke scepticism if a company is stigmatized beforehand with a bad reputation or if a company is experiencing a legitimacy threat such as a corporate scandal.

As it now stands most scholars studying the Web, recognize that web sites are very poorly used dialogic tools. In spite of the recommendations of scholars to incorporate two-way (and dialogic) communication channels most official web sites fail to effectively maintain open channels of communication with stakeholders. This study supports that trend. As indicated above, all companies studied employed poor dialogic communication, exhibited little commitment to building relationships with interested publics.

\section{Conclusion}

The research findings showed that the company has tried to show information about the CSR on its official web site. Especially information about the company profile and products and services. Information about social action, environmental action, the external criteria, and relationship with public received considerable attention 
from the company. Although seen from the observations that the information displayed is limited to qualitative information. Meanwhile, CSR issues that addressed to internal stakeholders, the corporate governance and employment and human resources, are limited to display on the website. Regarding to dialogic features, the companies not yet fully take advantage of the interactivity features to establish a dialogue with stakeholders.

\section{References}

- Adams, C.A. and G.R. Frost. (2006), “Accessibility and Functionality of the Corporate Web Site: Implications for the Sustainability Reporting”. Business Strategy and the Environment. Vol 15, pp. 275-287

- Branco, M. C. and L. L. Rodrigues. (2006), "Communication of Corporate Social Responsibility by Portuguese Banks: A Legitimacy Theory Perspective", Corporate Communications: An International Journal Vol 11(3), pp. 232-248.

- Capriotti, P. dan A. Moreno. (2007), "Corporate Citizenship and Public Relations: The Importance and Interactivity of Social Responsibility Issues on Corporate Websites”. Public Relations Review, Vol 33, pp. 84-91

- Carroll, A. B. (1979), "A Three-Dimensional Conceptual Model of Corporate Social Performance", Academy of Management Review, Vol. 4 No. 4, pp. 497-505.

- Jenkins, H.M. and Yakovleva, N. (2006), "Corporate social responsibility in the mining industry: exploring trends in social and environmental disclosure". Journal of Cleaner Production, 14 (3-4), pp. 271-284

- Deegan, 2000

- Esrock, S. L. and G. B. Leichty. (2000), “Organization of Corporate Web Page: Publics and Functions”, Public Relations Review, Vol 26(3), pp. 327-344.

- Freeman, R.E. (1984), Strategic Management. A Stakeholder Approach. Marshfield, MA: Pitman

- Gray, R.H., Owen, D.L., and Maunders, K.T. (1987). Corporate Social Reporting: Accounting and Accountability. Prentice-Hall, London.

- Isenmann R, and Lenz C. (2001), “Customized corporate environmental reporting by internet-based push and pull technologies". Eco-Management and Auditing, Vol 8, pp. 100-110.

- Jawahar, I. M. and McLaughlin, G. L. (2001) "Toward a Descriptive Stakeholder Theory: An Organizational Life Cycle Approach”, Academy of Management Review, Vol. 26 No. 3, pp. 397-414.

- Kent, M.L., M. Taylor, and W.J. White. (2003), “The Relationship between web site design and organizational responsiveness to stakeholders", Public Relation Review, Vol 29, pp. 63-77

- Mitchell, R.K., Agle, B. and Wood, D. (1997), "Toward a stakeholder identification and salience: defining the principle of who and what really counts", Academy of Management Review, Vol 22 No 4, pp. 853-886.

- Morsing, M. and M. Schultz. (2006),"'Corporate social responsibility communication: stakeholder information, response and involvement strategies", Business Ethics: A European Review, Vol 15 No 4 October 2006

- Smith, N.C. (2003). “Corporate social responsibility: whether or how?”. California Management Review, Vol 45 No 4, pp. 52-76.

- $\quad$ Snider, J., R. P. Hill and D. Martin. (2003), "Corporate Social Responsibility in the 21st Century: A View from the World's Most Successful Firms", Journal of Business Ethics, Vol 48(2), pp. 175-187.

- Unerman, J. (2000). 'Methodological Issues : Reflections on quantification in corporate social reporting content analysis'. Accounting, Auditing and Accountability Journal, Vol. 13, No.5, pp. 667-680. 